\title{
Vaccine hesitancy in East Malaysia (Sabah): A survey of the national COVID-19 immunisation programme
}

\author{
Adi Jafar, Mohammad Tahir Mapa, Nordin Sakke, Ramli Dollah, Eko Prayitno Joko, Colonius \\ Atang, Syahruddin Awang Ahmad, Chong Vun Hung, Fionna Geogre \\ Faculty of Social Sciences and Humanities, Universiti Malaysia Sabah, Kota Kinabalu, Sabah, Malaysia
}

\begin{abstract}
The Malaysian government has introduced the National COVID-19 Immunisation Programme (PICK) as a new mechanism to address the transmission of coronavirus disease 2019 (COVID-19). Unfortunately, the number of PICK registrations is still unsatisfactory and is now even lower. The low level of participation of the Sabah (East Malaysia) population significantly impacts the PICK registrations. Therefore, this study aims to identify the factors that cause vaccine hesitancy among the people of Sabah. This study seeks to identify these trends based on zone and district boundaries. A total of 1024 respondents were sampled in this study. Raw data collected through the survey method were analysed using K-means clustering, principal component analysis (PCA), and spatial analysis. The study discovered that factors including confidence, authority, mainstream media, complacency, social media, and convenience are the top causes of vaccine hesitancy among respondents. This study also revealed that the Sabah population's key variables causing vaccine hesitancy to vary by region (zones and districts). The conclusion is significant as a source of supporting data for stakeholders seeking to identify the Sabah population's constraints in each region and therefore, it would help improve PICK management's performance in Sabah.
\end{abstract}

Correspondence: Ramli Dollah, Faculty of Social Sciences and Humanities, Universiti Malaysia Sabah, 88400 Kota Kinabalu, Sabah, Malaysia.

Tel.: +60198139006. E-mail: ramlid@ums.edu.my

Key words: COVID-19; vaccine hesitancy; geographical information system; immunisation programme; East Malaysia.

Received for publication: 18 July 2021.

Revision received: 18 October 2021.

Accepted for publication: 18 October 2021.

(C) Copyright: the Author(s), 2022

Licensee PAGEPress, Italy

Geospatial Health 2022; 17(s1):1037

doi:10.4081/gh.2022.1037

This article is distributed under the terms of the Creative Commons Attribution Noncommercial License (CC BY-NC 4.0) which permits any noncommercial use, distribution, and reproduction in any medium, provided the original author(s) and source are credited.

\section{Introduction}

The global community is currently shocked by the coronavirus disease 2019 (COVID-19) transmission, which was first detected in the mid of December 2019 in Wuhan City, Hubei, China (WHO, 2020a; Jafar et al., 2021). The impacts of the widespread transmission led the World Health Organisation (WHO) to declare a worldwide health emergency by classifying COVID-19 as a pandemic (WHO, 2020b). At the same time, the World Health Organisation (WHO) also issues global guidelines, control, and infection prevention to all countries and communities as a preventive strategy against COVID-19 infection (Sharfuddin, 2020). Consequently, almost the entire world population, including Malaysia, are forced to adopt the new norm practices to break the chain of the pandemic spread. This new norm practice was initially a recommendation by the government, which later translated into standard operating procedures (SOPs) or movement control order (MCO). Each individual is compulsory to abide by the set SOPs such as using a face-covering in public areas, washing hands regularly, using hand sanitiser, observing physical distance, and checking body temperature before entering the premises (Wong et al., 2021). Not only that, the practice of SOPs in Malaysia also includes home-based online learning (Selvanathan et al., 2020; Coman et al., 2020), work from home practice (Hashim et al., 2020; Lee et al., 2020; Mumin, 2020), restrictions on overseas travel (Hafifi et al., 2021), and, limiting business operation hours (Ratnasingam et al., 2020).

Nevertheless, it is undeniable that the new norms in Malaysian daily life since March 2020 make people's lives even harder. The evidence is that the implementation of MCO or lockdown in Malaysia (Rahman et al., 2020) and several other countries (Brodeur et al., 2020) negatively impacts the economy, either at the individual or national level. Among them is the increase of the unemployment rate (Rahman et al., 2020) and loss of income (Sundarasen et al., 2020). Among the most affected sectors including tourism, hospitality, real estate, housing, aviation, and sport industries (Nicola et al., 2020). This condition indirectly catalyses other problems such as the increase in mental health problems (depression and anxiety), especially among young people, students, women, and the poor (Elengoe, 2020; Perveen et al., 2020; Wong et al., 2021). Yee et al. (2021) found that about one in three individuals in Malaysia experienced mild to severe depression during MCO. Therefore, it is not surprising if there is an increase in suicide cases during the MCO period, among others, due to factors of mental health problems (Dermawan, 2020; Wong et al., 2021; McCartan et al., 2021). This situation demonstrates that the long period implementation of MCO inadvertently causes new 
difficulties in society and country. Therefore, boosting herd immunity is the best solution to ensure that the people's social life returns to normal. To attain the goal, the Malaysian government has implemented the National COVID-19 Immunization Program (PICK). In this program, 80\% (23.6 million) of the Malaysian population would have received the vaccine by February 2022 (The Special Committee for Ensuring Access To COVID-19 Vaccine Supply, 2021). Studies have shown that to stop the virus, $60 \%$ to $90 \%$ of the total population needs to be vaccinated (Fine et al. 2011). However, other factors, such as the number of infections and the vaccine's efficiency, also influence the overall efficiency (Phizackerley, 2021; Kadkhoda, 2021).

Regrettably, the PICK registrations remains unsatisfactory due to the low enrolment (Ridauddin Daud, 2021). This low enrolment is greatly influenced by the level of participation of the Sabahans (East Malaysia). Based on the data, among all states in Malaysia, Sabah recorded the lowest percentage of vaccine registrations (Durie, 2021) to date (1 July 2021) (COVID-19, 2021) [Vaccine Supply Assurance Special Committee (JKJAV)]. Therefore, this study aims to identify the factors that cause vaccine hesitancy/refusal among the people of Sabah. This study seeks to identify this pattern based on the boundaries of zones and districts. It is critical to figure out whether vaccine reluctance factors are the same in each zone and district, or vice versa.

\section{Materials and methods}

\section{Study area and participants}

Sabah is one of the states in Malaysia with total population of 3,904,500 people (Department of Statistics Malaysia, 2021). A total of 1024 Sabahans were participating in the survey. Therefore, based on the Krejcie and Morgan (1970) Table, the sampling number for this study is considered sufficient to represent the study of the Sabah whole population. The sample in this study consisted of residents in the Northeast Zone (9.2\%), Southeast Zone (9.6\%), Southwest Zone (13.7\%), Interior Zone (17.6\%), Northwest Zone (21.9\%) and Midwest Zone (28.1\%). Except for the Midwest Zone (3 districts) and Northeast Zone (5 districts), the majority of Sabah's zones (Northwest Zone, Southwest Zone, Interior Zone, Southeast Zone) are made up of a combination of four districts (Figure 1).

\section{Questionnaire (Google Form)}

Respondents in this study were randomly selected and had answered the questions given through an online google form. Data collection process was carried out for about two weeks, from March 30, 2021 to April 15, 2021. The questions asked to respondents are in the form of a likert scale with five answer choices, namely ' 1 = strongly disagree,' $2=$ disagree, ' $3=$ less agree, ' $4=$ agree and' $5=$ strongly agree. All items (18 items) of the Likert scale question were negative. This means respondents who answered score 5 (strongly agree) demonstrated a very negative perception towards PICK while the answer score 1 (strongly disagree) had the opposite impression (Figure 2). The questions used in this study were adapted from Fauzi et al. (2016), Fauzi et al. (2018), Rumetta et al. (2020) and Sallam (2021).

\section{Statistical analysis}

This study employed several forms of analysis, including Kmeans clustering, principal component analysis (PCA), and spatial analysis. K-means clustering divides respondents based on the function of the method, which is to produce groupings of variables

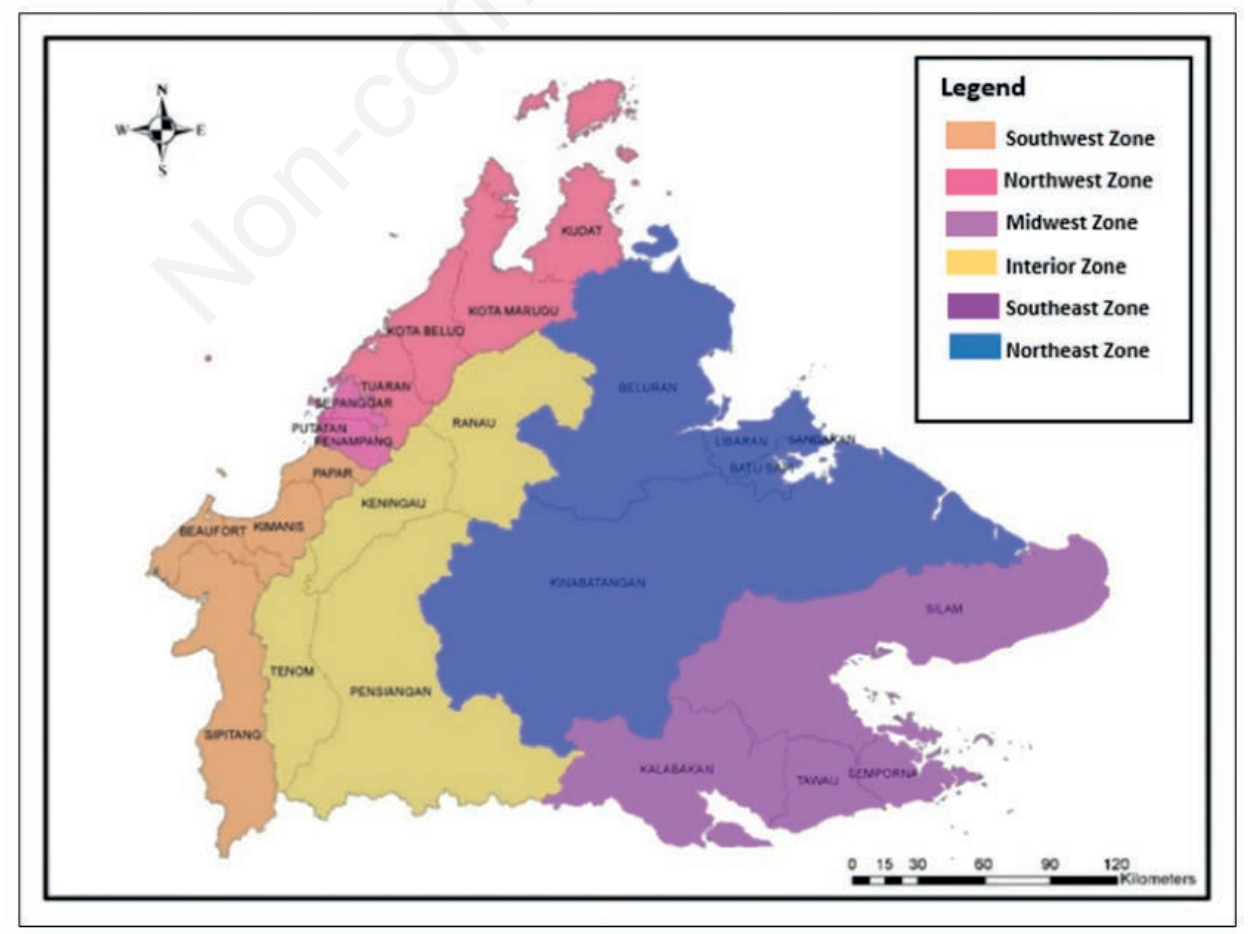

Figure 1. Position of zones and residents in the State of Sabah. Source: Modified from Sabab Town Planning, 2021. 
with a high degree of similarity within each group and a low degree of similarity between groups (Hastie et al., 2009; Morissette and Chartier, 2013). In general, to cluster a large amount of data, the K-Means technique (non-hierarchical clustering) is preferable because it has a higher speed than the Hierarchical clustering Technique (Johnson and Wichern, 2007; Damayanti and Wijayanto, 2021). Given that the sample size in this study falls into the large category (1024 respondents), the usage of the K-means technique is vital. The K-means algorithm defined above aims at minimizing an objective function, which in this case is the squared error function. The objective function for the K-means clustering algorithm is the squared error function. The formula are shown below:
$J=\sum_{i=1}^{k} \sum_{j=1}^{n}\left(\left\|x_{i}-v_{j}\right\|\right)^{2}=1$

where,

$\left\|x_{i}-v_{j}\right\|$ is the Eucledian distance between a point, $x_{i}$, and a centroid, $v_{j}$ iterated over all $\mathrm{k}$ points in the $i^{\text {th }}$ cluster, for all $n$ culsters.

Figure 3 demonstrates the elbow and silhouette graphs that were designed using machine learning analyses (Python). Both methods (elbow and silhouette method) were utilised to determine the best number of clusters (Rousseeuw, 1987; Damayanti and Wijayanto, 2021). Based on the two graphs, it is found that the answer can be divided into two main clusters (Cluster 1 and Cluster 2). The clustering results using K-means analysis revealed that respondents in Cluster 2 demonstrate a negative perception

\begin{tabular}{|c|c|}
\hline Aspect & Variable \\
\hline \multirow{10}{*}{$\begin{array}{l}\text { Internal } \\
\text { Factors }\end{array}$} & In1) Not convinced with the legality (halal) of the vaccine \\
\hline & In2) Vaccine is not safe for my body \\
\hline & In3) Vaccines are just a conspiracy \\
\hline & In4) Waiting for vaccines that are safer in the future \\
\hline & In5) Not convinced if vaccines can prevent Covid-19 transmission \\
\hline & In6) I am afraid to be injected \\
\hline & In7) Less interested in vaccines as many recover without vaccines \\
\hline & In8) The practice of SOPs is sufficient to prevent the transmission of Covid-19 without vaccines \\
\hline & In9) Still worried about being infected with Covid-19 even after being vaccinated \\
\hline & In10) Taking vaccines only when most people are vaccinated \\
\hline \multirow{8}{*}{$\begin{array}{l}\text { External } \\
\text { Factors }\end{array}$} & Ex1) Limited information regarding the Covid-19 immunisation programme \\
\hline & Ex2) Limited information regarding the vaccines \\
\hline & Ex3) Vaccine-related information in the mainstream media is not convincible \\
\hline & Ex4) Vaccine-related viral issues influenced me to not take the vaccine \\
\hline & Ex5) Internet access prevented me from registering for the Covid-19 immunisation programme \\
\hline & Ex6) Difficult registration process for the Covid-19 immunisation programme \\
\hline & Ex7) Objection from families to taking the vaccines \\
\hline & Ex8) Taking vaccines only when it is compulsory \\
\hline
\end{tabular}

Figure 2. Variables used to explain the factor of vaccine hesitancy among the Sabahan Community.

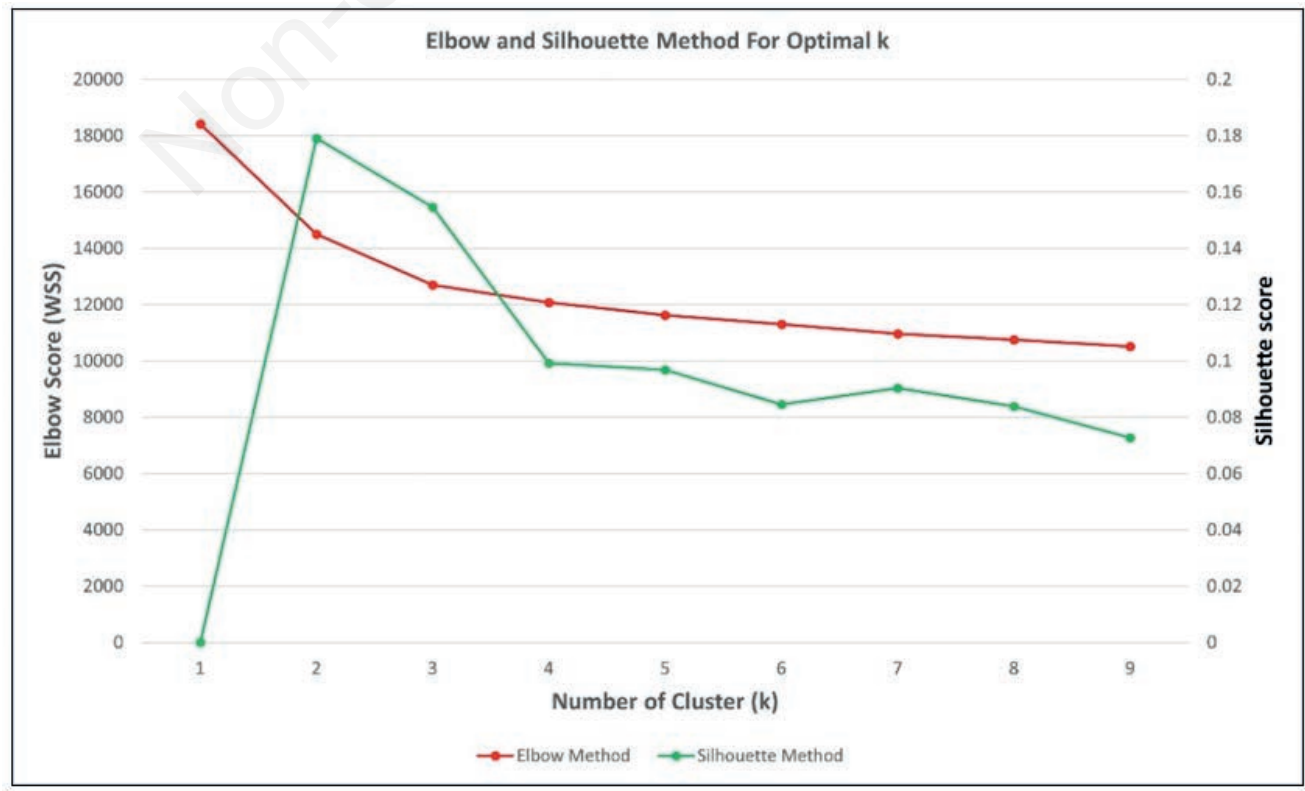

Figure 3. Cluster number determination technique based on the elbow and silhouette method. 
towards PIVCK compared to respondents in Cluster 1. This is evidenced when the Z-score values of all Cluster 2 variables are positive in values. In contrast to Cluster 1 , all its variables were found to have negative status $\mathrm{Z}$-score values (Figure 4). This indicates that the Cluster 2 respondents are among those who are hesitant or refuse to receive the vaccine (vaccine hesitancy). As a result, further analysis will only focus on Cluster 2.

The next step is conducting a PCA analysis using Cluster 2 The results of the PCA analysis are presented in the form of thematic maps using the geographical information system (GIS). The purpose of the thematic map is to demonstrate the distribution pattern of selected themes (Slocum et al., 2009). The factors of vaccine hesitancy will be presented using a choropleth map capable of showing the distribution of values based on colour tones. The classification approach employed is a natural break that optimizes classification by minimising variance within classes and increasing variance between them (Jenks, 1967).

Meanwhile, PCA is a multivariate technique that analyses a data table in which several inter-correlated quantitative dependent variables describe observations. Its goal is to extract the critical information from the statistical data to represent it as a set of new orthogonal variables called principal components (Mishra et al., 2018). The Bartlett's of Sphericity values should first be identified before forming the principal components (Yahya et al., 2019). In this study, Bartlett's test indicates a significant value $(\mathrm{P}<0.01)$. Therefore, the sample is eligible for factorisation and can be further analysed. Based on the Scree Plot readings, it was found that a total of six main components were successfully produced (Figure 5 ). The cumulative value of the variance of the six main components amounted to $61.81 \%$ (Table 1 ). This suggests that the six primary components influence up to $61.81 \%$ of vaccination hesitancy

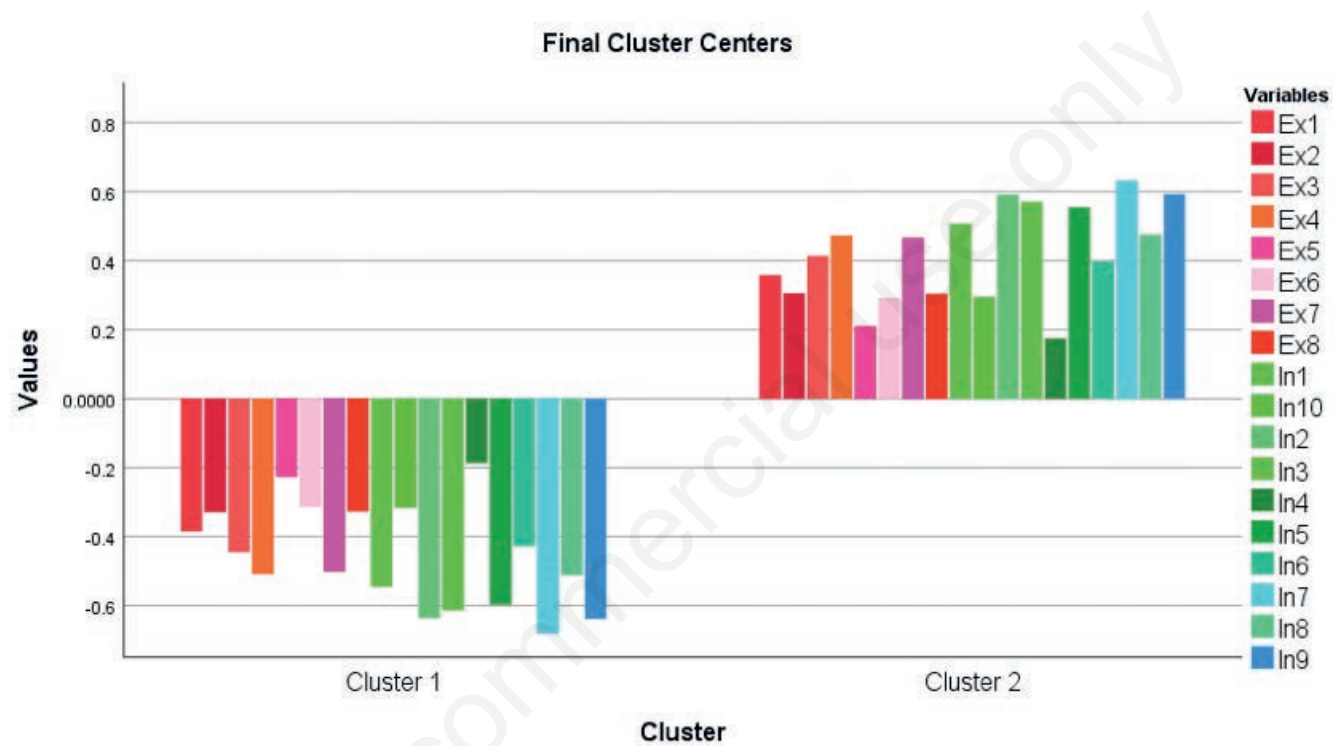

Figure 4. Community reaction towards PICK based on clusters.

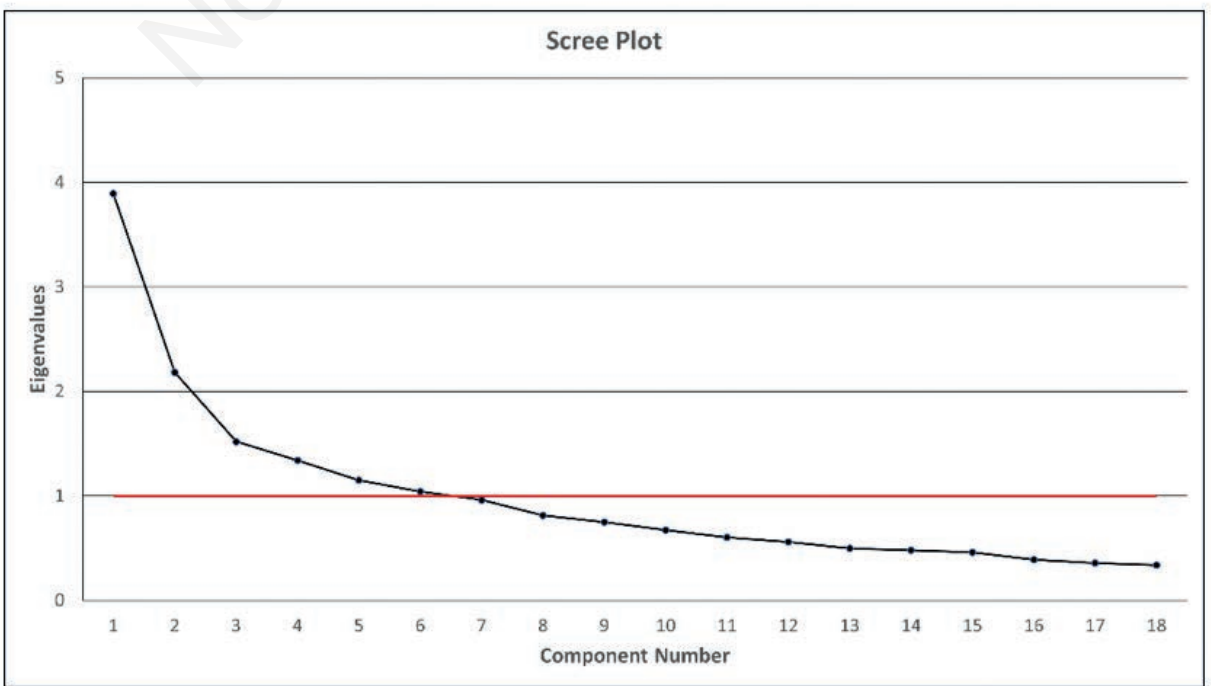

Figure 5. Number of components produced. 
Table 1. Variance and cumulative values of main components.

\begin{tabular}{llcc} 
Component & Total & Initial Eigenvalues & Cumulative \% \\
& \% Variance & 21.630 \\
1 & 3.893 & 21.630 & 33.747 \\
\hline 3 & 2.181 & 12.117 & 42.188 \\
4 & 1.519 & 8.441 & 49.636 \\
\hline 5 & 1.341 & 7.448 & 56.020 \\
6 & 1.149 & 6.384 & 61.807 \\
\hline 7 & 1.042 & 5.786 & 67.145 \\
$8-18$ & 0.961 & 5.338 & $71.66-100$ \\
\hline
\end{tabular}

Table 2. Demographic profile of respondents based on the vaccine hesitancy cluster.

\begin{tabular}{|c|c|c|c|}
\hline Item & Category & & \\
\hline & & Frequency & $\%$ \\
\hline Registration status & Registered & 198 & 37.3 \\
\hline & Unregistered & 333 & 62.7 \\
\hline Gender & Male & 246 & 46.3 \\
\hline & Female & 285 & 53.7 \\
\hline Age & $18-40$ & 438 & 82.5 \\
\hline & $>41$ & 93 & 17.5 \\
\hline Marital status & Single & 326 & 61.4 \\
\hline & Married & 205 & 38.6 \\
\hline Educational status & University & 310 & 58.4 \\
\hline & High school and below & 221 & 41.6 \\
\hline Employment status & Civil servants & 83 & 15.6 \\
\hline & Private sector employees & 130 & 24.5 \\
\hline & Self-employed & 98 & 18.5 \\
\hline & Not working & 70 & 13.2 \\
\hline & Student & 150 & 30.9 \\
\hline Total sample size & 531 & 100 & \\
\hline
\end{tabular}

factors, with the balance influenced by other factors (Nasution, 2019). Thompson (2004) and Hair et al. (2010) opined that only total variances exceeding $60 \%$ are acceptable. However, the explained variance in the humanities was commonly as low as 50 to $60 \%$ (William et al., 2010). As a result, the proportion of total variation in this analysis should be accepted. The following procedure is to determine the value of the loading factor of each variable. According to Fauzi et al. (2014) and Simanjuntak (2018), variables with loading factor values greater than 0.5 are significantly classified in the main components (Table 3 ).

\section{Results}

\section{Demographic profile of the vaccine hesitancy}

The demographic profile of the vaccine hesitancy cluster is shown in Table 2. The study found that more than half (62.7\%) of the respondents had not registered for PICK. In this cluster, the majority of respondents were female $(53.7 \%)$ compared to men $(46.3 \%)$, and those who single status were more $(61.4 \%)$ than those who were married $(38.6 \%)$. Therefore, it is not surprising that the majority $(82.5 \%)$ of this cluster consists of young people. In addition, more than half of the respondents in this cluster were university graduates.
Table 3. Analysis result of main component extraction.

\begin{tabular}{|c|c|c|c|c|c|c|}
\hline Item (Domain) & 1 & 2 & 3 & 4 & 5 & 6 \\
\hline $\begin{array}{l}\text { Confidence } \\
\text { In1 } \\
\text { In2 } \\
\text { In5 } \\
\text { In9 } \\
\text { Ex7 }\end{array}$ & $\begin{array}{l}0.763 \\
0.805 \\
0.761 \\
0.740 \\
0.636\end{array}$ & & & & & \\
\hline $\begin{array}{l}\text { Authority } \\
\text { In4 } \\
\text { In10 } \\
\text { Ex8 }\end{array}$ & & $\begin{array}{l}0.683 \\
0.809 \\
0.798\end{array}$ & & & & \\
\hline $\begin{array}{l}\text { Mainstream media } \\
\text { Ex1 } \\
\text { Ex2 } \\
\text { Ex3 }\end{array}$ & & & $\begin{array}{l}0.784 \\
0.771 \\
0.685\end{array}$ & & & \\
\hline $\begin{array}{l}\text { Complacency } \\
\text { In7 } \\
\text { In8 }\end{array}$ & & & & $\begin{array}{l}0.745 \\
0.840\end{array}$ & & \\
\hline $\begin{array}{l}\text { Social media } \\
\text { In3 } \\
\text { In6 } \\
\text { Ex4 }\end{array}$ & & & & & $\begin{array}{l}0.600 \\
0.671 \\
0.585\end{array}$ & \\
\hline $\begin{array}{l}\text { Convenience } \\
\text { Ex5 } \\
\text { Ex6 }\end{array}$ & & & & & & $\begin{array}{l}0.590 \\
0.783\end{array}$ \\
\hline
\end{tabular}




\section{Factors of vaccine hesitancy among the community in} Sabah

The PCA analysis conducted on the Cluster 2 respondents found six main factors (domain) that caused vaccine hesitancy in Sabah. The first is due to a confidence issue (Component 1) with a variance value of 21.63. On the other hand, the second factor is related to the authority issue (variance $=12.12$ ). Apart from that, mainstream media weakness (Component 3 ) also limits the success of PICK in Sabah (variance =8.44). This study also found that complacency issue (variance $=7.45$ ) and social media influence (variance $=6.38$ ) impact the respondents' decisions to not participate in PICK. The last factor that causes vaccine hesitancy is relat- ed to the convenience issue (Component 6), with a variance value of 5.79 .

\section{Factors of vaccine hesitancy based on geographical space in Sabah}

When examined in detail depending on the geographical location of Sabah, it is discovered that a variety of factors causes vaccination hesitancy. Most respondents living in the Southwest Zone, for example, reacted negatively towards PICK due to confidence issues $(Z$-scores $=0.1486$ ), particularly in the Papar district ( $Z$ scores $=0.3058)$. In contrast to the situation in the Southeast Zone, residents in the zone reacted negatively towards PICK due to

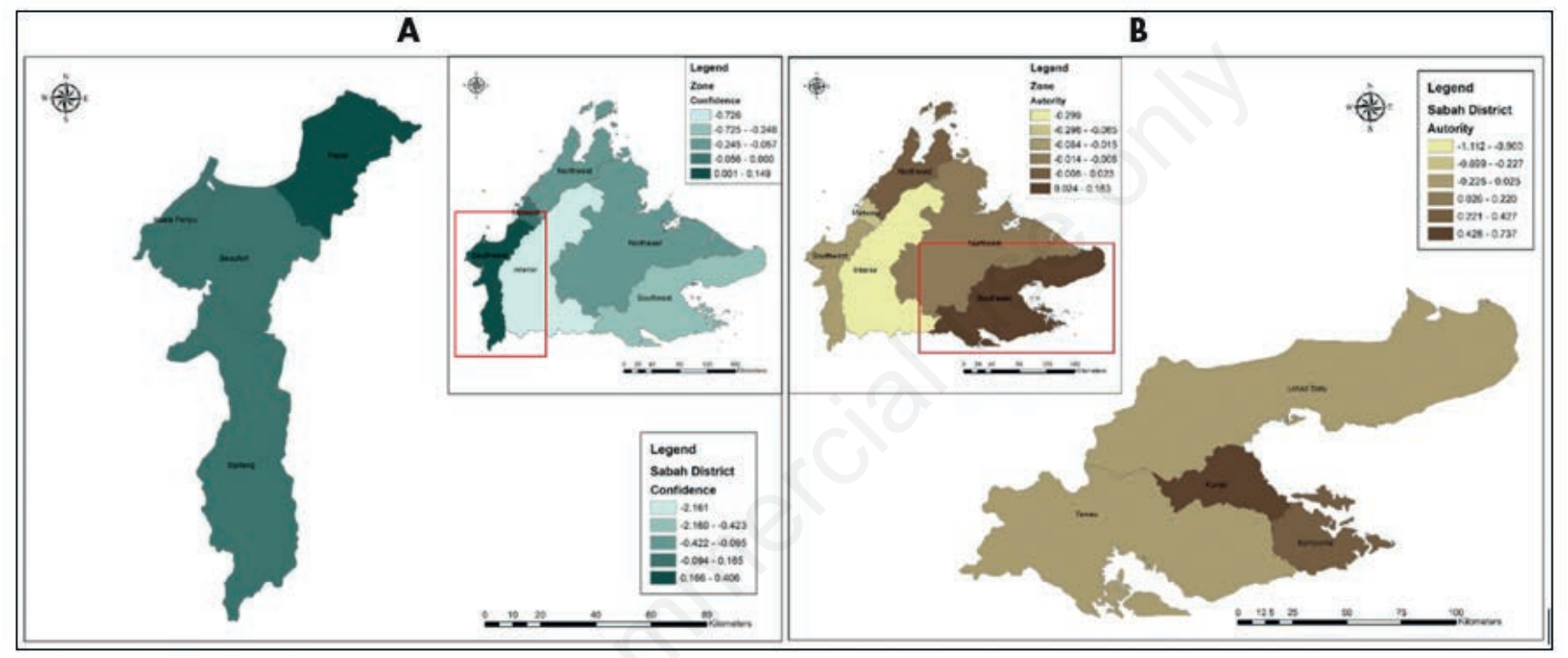

Figure 6. A and B) Factor of vaccine hesitancy due to confidence and authority issues.

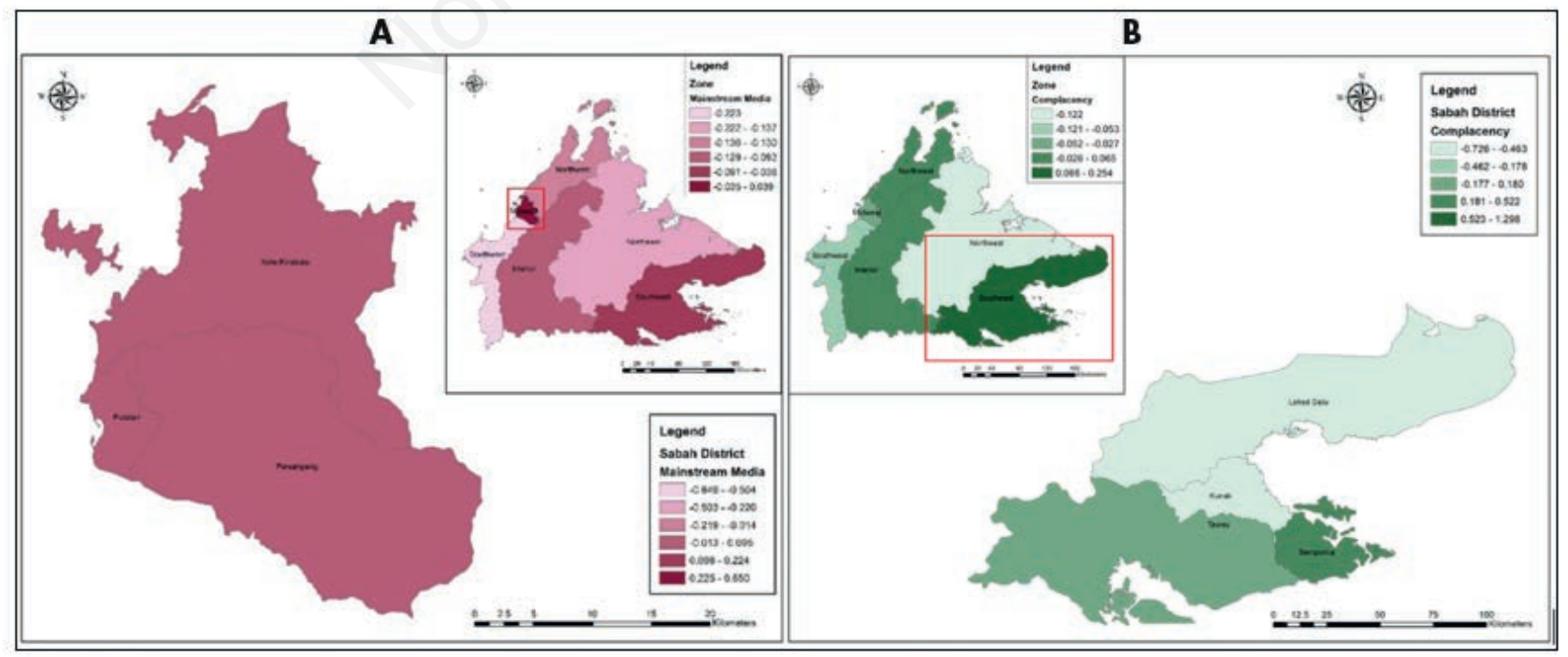

Figure 7. A and B) Factor of vaccine hesitancy due to weakness of mainstream media and complacency issues. 
authority ( $Z$-scores $=0.1529)$ and complacency issues (Z-scores $=0.2536$ ) (Figures $6 \mathrm{~B}$ and 7B). Respondents in Kunak district reacted the most negatively towards PICK due to authority issues with Z-scores value of 0.7371 (Figure 6B). Semporna district did not show interest in PICK due to complacency issues with a Zscores value of 0.3806 (Figure 7B). For the Midwest zone, most respondents in the area perceived negatively towards PICK due to the weakness of mainstream media $(Z$-scores $=0.0394$ ) (Figure 7A). Respondents who less agreed with PICK due to the social media influence were mainly in the Northeast Zone (Z-scores $=0.2522)$, particularly in Tongod $(Z$-scores $=0.8147)$ and Telupid districts ( $Z$-scores $=0.5045$ ) (Figure 8A). The study also found that most respondents living in the Interior zone find it challenging to participate in PICK due to convenience factors (Z-scores $=0.4767$ ), especially in Nabawan (Z-scores $=1.3878$ ) and Ranau districts (Zscores $=0.7622$ ) (Figure $8 B$ ).

\section{Discussion}

Respondents residing in different locations have their own reasons or limitations for participating in PICK. In other words, the vaccination reluctance factor varies by region in Sabah. According to the SAGE Working Group's 3C model, vaccination hesitancy is caused by three primary factors: complacency (poor understanding of the risks of diseases that vaccines can prevent), confidence (faith in health professionals, vaccines, and their effectiveness), and convenience (availability and accessibility to vaccines and health services) (MacDonald, 2015). Interestingly, this study found that three other additional factors cause vaccine hesitancy other than those raised by MacDonald (2015). The different factors include issues of authority and mainstream media and social media (Table 3). For residents residing in rural areas such as Tongod and Telupid Districts (Notheast Zone), most do not want to participate in PICK due to social media influence (Figure 8A). They readily believe in vaccine-related viral information and assumed that the vaccine is a conspiracy (Table 3). According to Rashid and Samat (2018), the level of education of rural communities in Malaysia is generally lower than urban communities. As a result, it is not surprising that the rural people in Sabah is more likely to believe negative social media viral information. This is due to the fact that education has a significant impact on a person's capacity to analyse, assess, and deduce information from social media (Purandina and Winaya, 2020). Moreover, the use of social media in the COVID-19 pandemic era was increasing (Wong et al., 2020). Residents living in Nabawan and Ranau Districts (Interior Zone) are less interested in participating in PICK due to Convenience issues (Figure 8B). The reason is relevant since basic infrastructure facilities in the interior zone, particularly the telecommunication network, are severely lacking (BERNAMA, 2021). Telecommunication network facilities are critical because vaccine registration techniques generally rely on internet channels (JKJAV, 2021). This situation is further complicated when none of the Vaccination Centres (PPV) located in Nabawan District (JKJAV, 2021).

Residents residing around the city centre (Midwest Zone) are less interested in participating in PICK due to the Weaknesses of the Mainstream Media (Figure 7A). Aside from not trusting the information obtained from the mainstream media, most of them also assumed that information on the COVID-19 vaccine in the media is still insufficient (Table 3). Hu and Kurokami (2017) found that urban communities, especially young people, have higher literacy levels and more critical thinking than rural communities. Due to this, the highly literate society is no longer easily influenced by the mainstream media (Tiung et al., 2018) which is often considered propaganda (Besar et al., 2015). The low reliance on mainstream media leads urban communities to use social media as an alternative source of information (Atmi et al., 2018). Residents residing in the Southeast Zone were less interested in PICK due to authority issues (Figure 6B) and complacency (Figure 7B). This is because most of them only want to be vaccinated when the government makes it mandatory for each individual or, after many of the population have been vaccinated (Table 3). Such actions are common as the Malaysian government does not make

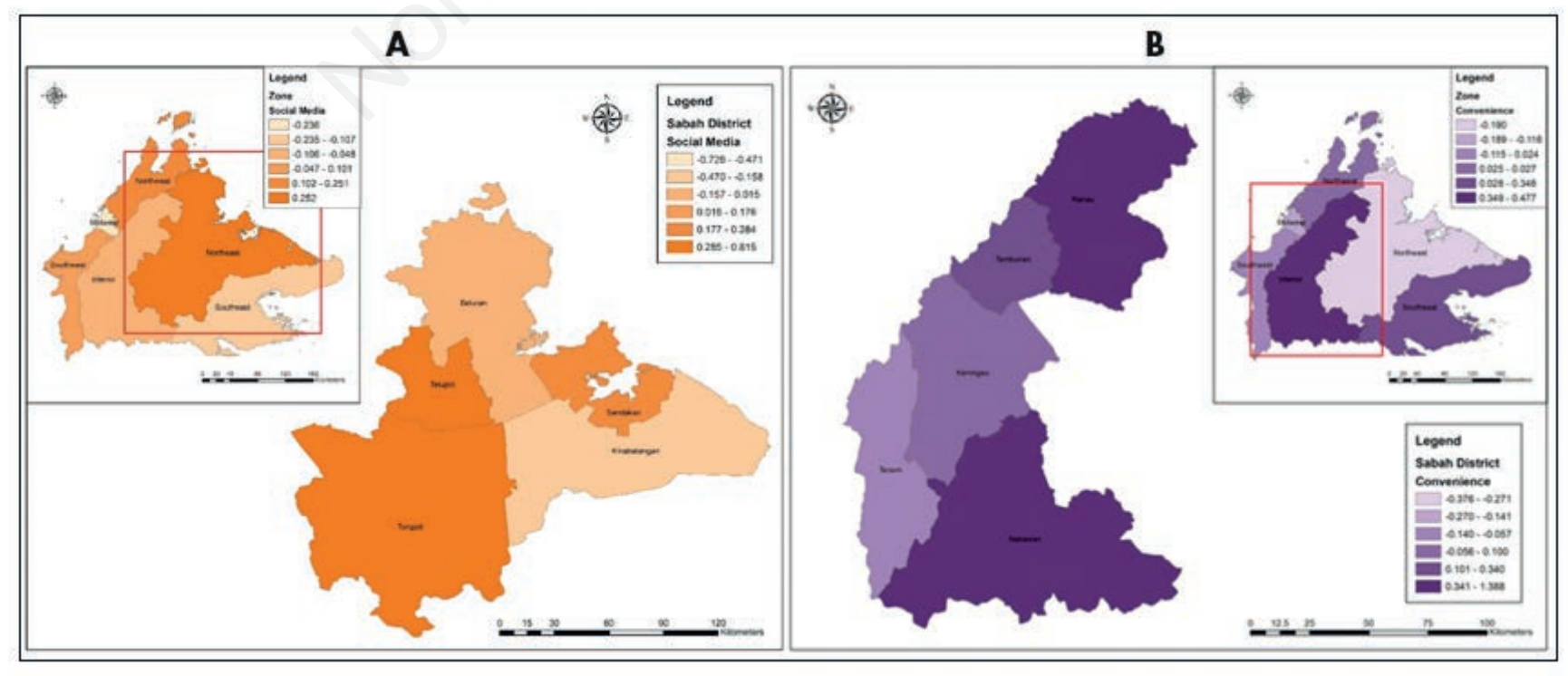

Figure 8. A and B) Factor of vaccine hesitancy due to social media influence and convenience. 
vaccination mandatory (JKJAV, 2021). With regard to complacency factor, respondents in the Southeast Zone assume that there is no need to take the vaccine as many COVID-19 patients recovered without being vaccinated. They also believed that SOP practices were adequate to prevent the transmission of COVID-19 even without vaccination (Table 3). Such perceptions indicate that the group believe the COVID-19 pandemic did not seriously harm. A similar response has been shown by a group of Muslims in several other countries such as Pakistan, Afghanistan, Nigeria, and South Africa. The group argues that humans are designed to naturally develop immunisation against viruses without using vaccines (Maravia, 2020). This understanding started from the interpretation of Qur' an verse that reads 'We have indeed created man in the best of molds' (The Qur'an, 2004). From the verse, this group believes the human body is 'miraculous in nature and more amazing than any scientific advancement that man can achieve' (Maravia, 2020). This suggests that religious beliefs influence a person's behaviour to decide whether to take the vaccine or vice versa.

\section{Conclusions}

In conclusion, this study found that the constraints faced by residents in Sabah to participate in PICK are different in each area. These constraint factors can generally be grouped into six main domains: confidence, authority, mainstream media weaknesses, complacency, social media influence, and convenience issues. The existence of different constraint factors in each area demands the stakeholders to be more aware in solving the problem. This is because no specific method is suitable to be applied to solve the problem in all the areas that experience different constraints. As a result, each sector requires a different approach. The federal agencies which were responsible for the vaccination program should provide channels for locals in Sabah for them to be heard of especially on issues related to the efficiency of the vaccine itself.

This study's outcomes would help stakeholders better identify problems or constraints experienced by the community of Sabah (East Malaysia) in each location. This will make it easier to manage PICKs more effectively and systematically.

\section{References}

Atmi RT, Satibi IF, Cahyani IR, 2018. Media literacy skills and social media: A portray of teenagers in urban area. Int J Engine Technol 7:236-9.

Besar JA, Jali MFM, Lyndon N, Yusof ARM, Choy LK, Ghazali AS, Ghani MHA, 2015. Pengaruh Geopolitik Popular Terhadap Gelagat Politik Pengundi Muda Universiti Awam di Lembah Klang (The Influence of Popular Geopolitics on the Political Behavior of Young Voters of Public Universities in the Klang Valley). Geografia 3:37-44.

BERNAMA, 2020. Senators call for Sabah Internet access issues to be resolved. Selangor Journal; 08 September. Available from: https://selangorjournal.my/2020/09/senators-call-forsabah-internet-access-issues-to-be-resolved/ Accessed: 23 March 2021.

Brodeur A, Gray DM, Islam A, Bhuiyan S, 2020. A literature review of the economics of COVID-19. Available from:
https://www.econstor.eu/bitstream/10419/222316/1/GLO-DP0601.pdf. Accessed: 21 March 2021.

Coman C, Țîru LG, Meseșan-Schmitz L, Stanciu C, Bularca MC, 2020. Online teaching and learning in higher education during the coronavirus pandemic: students' perspective. Sustainability 12:10367.

COVID-19 Vaccine Supply Assurance Special Committee, 2021. Trending statistics of the National COVID-19 Immunisation Programme. Available from: https://www.vaksinCOVID. gov.my/en/ Accessed: 19 May 2021.

Damayanti AR, Wijayanto AW, 2021. Comparison of hierarchical and non-hierarchical methods in clustering cities in Java Island using the human development index indicators year 2018 . Eigen Math J 4:8-17.

Department of Statistics Malaysia, 2021. Population and housing census of Malaysia. Available from: https://www.mycensus. gov.my/index.php/ms/125-newsletter-infographics/1646-scdpsabah Accessed: 23 April 2021.

Durie Rainer Fong, 2021. Sabah's low vaccine registration number worries state rep; 26 March. Available from: https://www. freemalaysiatoday.com/category/nation/2021/03/26/sabahslow-vaccine-registration-number-worries-state-rep/ Accessed: 29 March 2021.

Elengoe A, 2020. COVID-19 outbreak in Malaysia. Osong Public Health Res Perspect 11:93-100.

Fauzi H, Jamali A, Mohd SZN, 2014. SPSS Research Methods \& Data Analysis. Universiti Utara, Malaysia.

Fauzi TFATM, Razif NFM, Ramli MA, 2018. Polemics between acceptance and rejection of children's vaccination: an analysis from Islamic perspective. Shariah J 26:201-30.

Fauzi TFATM, Razif NFM, Sharifuddin NM, 2016. Vaccination of children according to the perspective of Maqasid al-Shariah. Appl Aspects Sci Technol 75-100.

Fine P. Eames K, Heymann DL, 2011. 'Herd immunity': a rough guide. Clin Infect 52:911-6.

Hafifi RR, Shah MMZ, Hafiza RR, Yusoff WW, Zulkifli MM, 2021. Reopening national border and the treat of COVID-19 towards Malaysia: a systematic review approach. The importance of new technologies and entrepreneurship in business development in the context of economic diversity in developing countries. Impact New Technol Entrepreneurs Business Develop 2106-30.

Hair JF, Black WC, Babin BJ, Anderson RE, 2010. Multivariate data analysis: a global perspective. Pearson Prentice Hall, New Jersey, USA.

Hashim R, Bakar A, Noh I, Mahyudin HA, 2020. Employees' job satisfaction and performance through working from home during the pandemic lockdown. Environ-Behav Proc J 5:461-7.

Hastie T, Tibshirani R, Friedman J, 2009. The elements of statistical learning: data mining, inference, and prediction. Springer Science \& Business Media, Berlin, Germany.

$\mathrm{Hu}$ X, Kurokami H, 2017. A comparison of media literacy in urban and rural middle school students. Int J Educ Media Technol 11:132-40.

Jafar A, Geogre F, Mapa MT, Sakke N, Dollah R, 2021. Perceptions of urban poor with B40 status on the impact of the implementation of movement control order (MCO) by employment sector: a case study of Kota Kinabalu City, Sabah. J Contemp Issues Business Govern 27:3603-18.

Jawatankuasa Khas Jaminan Akses Bekalan Vaksin COVID-19, 2021. Trending statistics of the National COVID-19 
Immunisation Programme. Available from: https:// www.vaksinCOVID.gov.my/en/ Accessed: 28 May 2021.

Jenks GF, 1967. The data model concept in statistical mapping. Int Yearbook Cartograp 7:186-90.

Johnson RA, Wichern DW, 2007. Applied multivariate statistical analysis, Sixth Edition. Springer, Berlin, Germany.

Kadkhoda K, 2021. Herd immunity to COVID-19: alluring and elusive. Am J Clin Pathol 155:471-2.

Krejcie RV, Morgan DW, 1970. Determining sample size for research activities. Educ Psychol Measure 30:607-10.

Lee NFC, Qi CJ, Mansur K, Mahmud R, 2020. The impact of coronavirus (COVID-19) on e-business in Malaysia: a review. In The 1 st International Conference on Entrepreneurship and Small Business (ICES2020).

MacDonald NE, 2015. Vaccine hesitancy: definition, scope and determinants. Vaccine 33:4161-4.

Maravia Usman, 2020. Vaccines: Religio-cultural arguments from an Islamic perspective. Project: congregating during COVID19: islamic jurisprudential and ethical considerations. Available from: https://www.researchgate.net/publication/ 348078005_Vaccines_Religiocultural_arguments_from_an_isl amic_perpective Accessed: 23 March 2021.

McCartan C, Adell T, Cameron J, Davidson G, Knifton L, McDaid $\mathrm{S}$, Mulholland C, 2021. A scoping review of international policy responses to mental health recovery during the COVID-19 pandemic. Health Res Policy Systems 19:1-7.

Mishra SP, Sarkar U, Taraphder S, Datta S, Swain DP, Saikhom R, Laishram M, 2017. Multivariate statistical data analysis-principal component analysis (PCA). Int J Livestock Res 7:60-78.

Morissette L, Chartier S, 2013. The k-means clustering technique: general considerations and implementation in mathematics. Tutor Quant Methods Psychol 9:15-24.

Mumin N, 2020. Are Malaysians ready for telecommuting? a case of COVID-19 movement control order. J Crit Rev 7:3979-90.

Nasution MZ, 2019. Penerapan Principal Component Analysis (PCA) dalam Penentuan Faktor Dominan yang Mempengaruhi Prestasi Belajar Siswa (Studi Kasus: SMK Raksana 2 Medan). JurTI (Jurnal Teknologi Informasi) 3:41-8.

Nicola M, Alsafi Z, Sohrabi C, Kerwan A, Al-Jabir A, Iosifidis C, Agha R, 2020. The socio-economic implications of the coronavirus and COVID-19 pandemic: a review. Int J Surg 78:185-93.

Perveen A, Hamzah H, Ramlee F, Othman A, Minhad M, 2020. Mental health and coping response among Malaysian adults during COVID-19 pandemic movement control order. J Crit Rev 7:653-60.

Phizackerley D, 2021. COVID-19 vaccination - we need more than the 'mum test'. Available from: https://dtb.bmj.com/content/ dtb/59/1/2.full.pdf Accessed: 7 April 2021.

Purandina IPY, Winaya IMA, 2020. Character in digital literacy: maintaining the peace of the people in the digital age. Jayapangus Press Books 1-18.

Rahman AA, Jasmin AF, Schmillen A, 2020. The vulnerability of jobs to COVID-19: the case of Malaysia. ISEAS-Yusof Ishak Institute.

Rashid SMRA, Samat N, 2018. Family poverty and its influence on rural community low education: Case study in Bachok District, Kelantan. e-Bangi 15(2). Available from: https://ejournal.ukm.my/ebangi/article/view/26796/8239 Accessed: 15 April 2021.

Ratnasingam J, Khoo A, Jegathesan N, Wei LC, Abd Latib H, Thanasegaran G, Amir MA, 2020. How are small and medium enterprises in Malaysia's furniture industry coping with COVID-19 pandemic? Early evidences from a survey and recommendations for policymakers. BioResour 15:5951-64.

Ridauddin Daud, 2021. The number of vaccine registration is still low - Khairy Jamaluddin. Astro Awani. Available from: https://www.astroawani.com/berita-malaysia/number-vaccineregistration-still-low-khairy-jamaluddin-285431

Rousseeuw PJ, 1987. Silhouettes: a graphical aid to the interpretation and validation of cluster analysis. J Computat Appl Math 20:53-65.

Rumetta J, Abdul-Hadi H, Lee YK, 2020. A qualitative study on parents' reasons andrecommendations for childhood vaccination refusal in Malaysia. J Infect Public Health 13:199-203.

Sabah Town Planning, 2021. Map of development control division in Sabah. Available from: https://www.townplanning. sabah.gov.my/Bahagian\%20Kawalan\%20Pembangunan.html

Sallam M, 2021. COVID-19 vaccine hesitancy worldwide: A concise systematic review of vaccine acceptance rates. Vaccines $9: 160$.

Selvanathan M, Hussin NAM, Azazi NAN, 2020. Students learning experiences during COVID-19: Work from home period in Malaysian Higher Learning Institutions. Teaching Public Administration 0144739420977900.

Simanjuntak IM, 2018. Use of principal component analysis (PCA) method to reduce factors affecting coronary heart disease in hospitals. H. Adam Malik Medan Tahun, 2017. Available from: http://repositori.usu.ac.id/ bitstream/handle/123456789/11234/141000025.pdf?sequence=1\&isAllowe d=y Accessed: 27 March 2021.

Sharfuddin S, 2020. The world after COVID-19. The Round Table 109:247-57. Available from: https://www.tandfonline.com/ doi/full/10.1080/00358533.2020.1760498 Accessed: 23 March 2021.

Slocum TA, McMaster RB, Kessler FC, Howard HH, 2009. Thematic cartography and geovisualization. 3rd ed. PearsonPrentice Hall, Upper Saddle River, NJ, USA.

Sundarasen S, Chinna K, Kamaludin K, Nurunnabi M, Baloch GM, Khoshaim HB, Sukayt A, 2020. Psychological impact of COVID-19 and lockdown among university students in Malaysia: Implications and policy recommendations. Int J Environ Res Public Health 17:6206.

The Special Committee For Ensuring Access To COVID-19 Vaccine Supply (JKJAV), 2021. National COVID-19 Immunisation Programme; 1 July Available from: https://www.vaksinCOVID.gov.my/pdf/National_COVID19_Immunisation_Programme.pdf. Accessed: 22 May 2021.

The Qur'an, 2004. Sura al-Tin; 95: 4. Abul-Qasim Publishing House. Available from: https://muslimcouncil.org.hk/wp-content/uploads/2019/01/Quran-English.pdf. Accessed: 23 March 2021.

Thompson B, 2004. Exploratory and confirmatory factor analysis. American Psychological Association, Washington, DC, USA.

Tiung LK, Idris RZ, Idris R, 2018. Propaganda and disinformation: politics of perception in Malaysian's 14th general election (Ge14). Jurnal Kinabalu, Special Issue, p. 171.

Williams B, Onsman A, Brown T, 2010. Exploratory factor analysis: A five-step guide for novices. Austral J Paramed 8:1-13.

Wong A, Ho S, Olusanya O, Antonini MV, Lyness D, 2020. The use of social media and online communications in times of pandemic COVID-19. J Intens Care Soc 1751143720966280.

Wong LP, Alias H, Md Fuzi AA, Omar IS, Mohamad Nor A, Tan 
MP, Chung I, 2021. Escalating progression of mental health disorders during the COVID-19 pandemic: evidence from a nationwide survey. PLoS One 16:e248916.

World Health Organization, 2020a. Situation report - 151 Coronavirus disease 2019 (COVID-19). Available from: https://www.who.int/docs/default-source/coronaviruse/situation-reports/20200619-COVID-19-sitrep-151.pdf?sfvrsn= 8b23b56e_2 Accessed: 12 June 2021.

World Health Organization, 2020b. Coronavirus disease 2019 (COVID-19): situation report, 82. Available from:
https://apps.who.int/iris/bitstream/handle/10665/331780/nCo Vsitrep11Apr2020-eng.pdf Accessed: 23 March 2021.

Yahya MSS, Masdar NF, Samat N, 2019. The use of factor analysis to determine the driving factors of household poverty in the Northern Region of Peninsular Malaysia. e-Bangi 16(6).

Yee A, Hodori NAM, Tung YZ, Ooi PL, Latif SABA, Isa HM, Tan SB, 2021. Depression level and coping responses toward the movement control order and its impact on quality of life in the Malaysian community during the COVID-19 pandemic: a web-based cross-sectional study. Ann Gener Psychiat 20:1-9. 